\title{
The Paleoparasitology in Brazil and Findings in Human Remains from South America: A Review
}

\author{
Shênia Patrícia Corrêa Novo*, Luiz Fernando Ferreira \\ Fundação Oswaldo Cruz, Fiocruz, Escola Nacional de Saúde Pública Sergio Arouca, ENSP, Departamento de Ciências Biológicas, DCB, \\ Laboratório de Paleoparasitologia Eduardo Marques, Rio de Janeiro, RJ, Brasil
}

\begin{abstract}
The review article presents some of the history of how paleoparasitology started in Brazil, making highlight the great responsible Dr. Luiz Fernando Ferreira and Dr. Adauto Araújo, the trajectory of paleoparasitology in Brazil since 1978 and its performance in science to the present day. In sequence, it is made a presentation of parasitological findings on human remains found in archaeological sites in South America, highlighting Brazil, Argentina, Chile, and Peru, where major discoveries have occurred. Many of the parasites found in archaeological material and mentioned in this review went out of Africa with the peopling of Europe and from there they dispersed around the world, where climatic conditions allow the transmission. However, humans have acquired other parasites of animals, since humans invaded new habitats or creating new habits adopting new technologies, thus expanding its range of influence on the environment. Thus, this review article is finalized with information that explain the importance of these findings in the interaction between parasites, human host, and ambient.
\end{abstract}

Key words: Paleoparasitology, paleoparasitology in Brazil, South America, human remains, review

\section{INTRODUCTION}

The paleoparasitology in Brazil - How it all began?

As a branch of paleopathology, aimed at meeting parasitic forms in archaeological material, the paleoparasitology is gaining more space in the scientific world. Not failing to mention the pioneering work of Sir Marc Armand Ruffer, to publish, in 1910, the finding of Schistosoma hematobium eggs in kidney tissue of Egyptian mummies [1]. Subsequently, Lothar Szidat [2] studying 2 bodies discovered in bogs of Prussia, found eggs of Trichuris trichiura and Ascaris lumbricoides.

In South America, paleoparasitology developed with the first studies conducted in Brazil. It was in the 1970s, specifically in 1978, with Dr. Luiz Fernando Rocha Ferreira da Silva, at the Laboratory of Paleoparasitology Eduardo Marques, located in the Department of Biological Sciences, DCB, the National School of Public Health Sergio Arouca, ENSP, Oswaldo Cruz

- Received 4 June 2016, revised 8 August 2016, accepted 17 August 2016.

*Corresponding author (shenia@ensp.fiocruz.br)

(c) 2016, Korean Society for Parasitology and Tropical Medicine

This is an Open Access article distributed under the terms of the Creative Commons Attribution Non-Commercial License (http://creativecommons.org/licenses/by-nc/4.0) which permits unrestricted non-commercial use, distribution, and reproduction in any medium, provided the original work is properly cited.
Foundation, Fiocruz, that paleoparasitology in Brazil, including this term was created. The great interest of this paleoparasitologist was whether parasitic infections had arrived in the Americas with the colonizers and slaves or would already be on the American continent before colonization [3]. The union with Dr. Adauto José Gonçalves de Araújo, in 1978, made the paleoparasitology in Brazil take flight. An article by Professor Benjamin Caio Dias who defended the autochthonous character of Schistosomiasis mansoni in the national territory, against all orthodoxy, was the runway for takeoff of the paleoparasitology in Brazil. There were no eggs of $S$. mansoni in coprolites analyzed. However, there were found hookworm eggs, which were also considered import. This allowed us to consider the question of humans' entry into America. In 1972, Fonseca [4] already discussed the possibility of infection by hookworms in America in pre-Columbian times, based on chroniclers' documents in the 17th century and parasitological tests in isolated indigenous tribes without contact with colonizers. Thus, under the orientation of Dr. Luiz Fernando Ferreira, Adauto Araújo received his master's degree in parasite biology in 1980, by Oswaldo Cruz Foundation with the study "Contribution to the helminth study of archaeological material in Brazil."

The passage through the Bering Strait as the only alternative 
for humans' entry in America as well as hookworm, was the big question. Being a geohelminth needed maturation in the soil, cold temperatures would have destroyed the parasite eggs. That was the idea defended by Dr. Adauto Araújo in his doctoral thesis in public health at the Oswaldo Cruz Foundation in 1987, with the study "Paleoepidemiology of the ancylostomiasis" under the orientation of Dr. Luiz Fernando Ferreira. These findings suggest, in fact, alternative routes, by sea, as a possibility for human migrations in prehistoric America, making questionable the absolute exclusivity of the Bering Strait as a gateway [5]. This is a line, whose results are accumulated until the present day, creating consistent data for discussions about the origin of host populations in new territories [6].

Shortly thereafter, Dr. Adauto Araújo made contact with Canadians studying paleoclimate and confirmed his hypothesis. As a famous book for the time: "The KonTiki expedition", where the author after consultation with Indians on Lake Titicaca built a boat with methodology of prehistory and managed to reach Polynesia leaving America. Thus, it was confirmed the possibility of crossing also by sea.

Although much of the studies of parasites in archaeological material in South America has been made with mummies of the Andean region [7], the interest also came by parasites of animals from coprolite studies found in archaeological layers [8]. Associating with Dr. Niéde Guidon on studies in the Serra da Capivara National Park, Piauí, Brazil, a series of observations came. One of the thatched houses was considered at the time the basis of Chagas disease. Dr. Adauto Araújo noted that when copying the cave pictures archeologists were attacked by triatomine bugs. Then, he raised the possibility that these insects could also attack the ancient inhabitants of these caves. Nailed it, managing to highlight the Trypanosoma cruzi infection, there are 3,500 years [9]. When man came in America, he was exposed to infection. Long before the thatched house, the man was infected. It was a very important work.

Collaborations have grown within Brazil, with several institutions of research, as well as the number of samples to be analyzed. The paleoparasitology in the country continues to grow with Dr. Adauto Araújo and Dr. Luiz Fernando Ferreira. The contributions go beyond the country's frontiers. In 2002 and 2009, Dr. Adauto Araújo held 2 postdocs at the University of Nebraska in Lincoln, USA. From there emerged the great partnership with Dr. Karl Reinhard. Research projects have continued yielding partnerships in several places, such as the National University of Mar del Plata, Argentina; University of
Reims, France; University of Tarapaca, Arica, Chile; University of Turin, Italy; Natural History Museum, Paris, France; and many others.

Until today, the techniques of optical microscopy after rehydration and spontaneous sedimentation of organic material and sediments for the diagnosis of eggs and larvae of parasites $[10,11]$ are often used in the Laboratory of Paleoparasitology Eduardo Marques, DCB, ENSP, Fiocruz. Samples of bone and visceral tissues are also analyzed in search of parasitic DNA fragments in these samples. For this, molecular biology techniques are applied, being the most used, i.e., PCR [12-16].

The first tests with the application of molecular biology to confirm the infection by T. cruzi in Chilean and Peruvian mummies were made in the Oswaldo Cruz Foundation, Rio de Janeiro, Brazil, in studies conducted by the team of paleoparasitology. Before the tests were applied in the archaeological material, experimental protocols were made in mice infected with known parasite load. After sacrificing the animals, the bodies were placed in oven at $40^{\circ} \mathrm{C}$ until complete desiccation. After this experimental "mummification", molecular biology techniques were applied until they reached a standard to be used in the archaeological material. That was the doctoral thesis of Otilio Machado Bastos, whose experiment was reported in the journal, Paleopathology Association [17], and applied by Guhl et al. [18] successfully in Chilean mummies in 2000.

Molecular biology techniques also allow the study of genetic evolution of parasites and the time of its introduction in human populations [19]. Retrieving ancient DNA (aDNA) of the parasite sequences and genotyping of these parasites increases the possibility of reconstruction of these current dispersion patterns [20]. Molecular biology techniques are also applied in the diagnosis of intestinal parasites, when the diagnosis is negative by optical microscopy or for confirmation of findings by this technique.

However, immunodiagnostic techniques have been successfully applied in some studies for the identification of protozoa, such as Giardia duodenalis and Entamoeba histolytica, as far outside Brazil as in our laboratory [21-23]. Currently, the Laboratory of Paleoparasitology Eduardo Marques follows with projects for the standardization of immunodiagnostic techniques for identification of specific parasites, such as the genus Leishmania, as well as the standardization of serological techniques for detection of parasite antigens in archaeological remains.

Concomitantly with analysis of parasites, the macro- and 
microscopic analyses of coprolites are carried out in our laboratory since the creation of paleoparasitology in Brazil, with the collaboration of Dr. Sergio Augusto de Miranda Chaves. This analysis may reveal important information about the dietary pattern, paleoclimate, and paleoecological adaptations [24]. The types of organic residues found in coprolites, such as pollen, fiber, starch grains, and bone fragments, in addition to the local archaeological context where coprolites were found, allow inferences about cultural information of ancient peoples. Thus, the practice of agriculture can be identified from the meeting of some plant varieties.

The paleoparasitology in Brazil also collects interesting and funny stories, such as transport of corpses and coprolites for studies in the Laboratory of Paleoparasitology when it was allowed to do this without so many bureaucracies (personal communication, Prof. Dr. Luiz Fernando Ferreira).

Today, the paleoparasitology is without a star, Dr. Adauto Araújo. However, this star continues to shine. He has left all of us many lessons, a wealth of knowledge. He is greatly missed by all who lived and worked with him. He contributed only way to the paleoparasitology worldwide. Thus, the Laboratory of Paleoparasitology Eduardo Marques, Department of Biological Sciences, DCB, continues to collect stories, carry out research, train students, and enrich paleoparasitology in Brazil, together with Dr. Luiz Fernando Ferreira, largely responsible for its existence! After all, "we do not want to reconstruct the past. What we want is to find data to make the present better and more intelligible" (Adauto Araújo). Lots of students, today's professionals were formed by Dr. Adauto Araújo and Dr. Luiz Fernando Ferreira and now have the role of seeds of paleoparasitology. Many of them continue to develop their work of master's, doctoral, and post-doctoral inside and outside Brazil. Partnerships continue. The paleoparasitology continues to grow.

The paleoparasitology studies not only in Brazil but by institutions outside the country cover the analysis of archaeological remains originating not only from humans, but also from animals. However, this review consists of an overview of studies related to parasites found in human remains.

This article starts counting as paleoparasitology was born in Brazil and does a review of some paleoparasitological findings of human remains in regions of South America, ending with the importance of these findings in the interaction between parasites, human hosts, and ambient [25].

\section{THE PALEOPARASITOLOGY IN SOUTH AMERICA}

Initially, paleoparasitology in South America was characterized by isolated studies, especially when the material was sent by archaeologists to any known parasitologist, who then described the results [7]. Gradually, research groups were forming and growing in Peru [26], Chile [27], and Argentina [28]. Without much pretension, it can be said that the birth of paleoparasitology in Brazil strongly influenced the organization of other groups dedicated to it in various parts of the world, making it evolve and change knowledges about diseases and parasitic infections in ancient times of humanity [29].

The paleoparasitological data in South America indicate intestinal parasitosis in prehistoric times, and thus, change the classic concept that would come from the European colonizers or trafficking in African slaves, going against the pre-established concepts that said most tropical diseases they would have been brought from Africa to the Americas [30,31].

One of the first paleoparasitology findings was obtained in South America by Pizzi and Schenone [32] in 1954, to find Enterobius vermicularis in pre-Columbian Chilean mummy dated 4,000-2,000 years B.P. (before present). Since then, several studies have been conducted. Many parasites found in archaeological material from South America are from Africa and are parasites of humans, since pre-hominid ancestors and humans reached the Americas long before the Iberian navigators, with this important biological markers of prehistoric migrations $[8,33]$.

Below are mentioned as some of the paleoparasitological studies in samples from archaeological sites in Brazil, Argentina, Chile, and Peru.

\section{PALEOPARASITOLOGICAL FINDINGS IN SAMPLES FROM BRAZIL}

The hookworm eggs found in human coprolites originating from archaeological sites Boqueirão da Pedra Furada and Sítio do Meio, located in the Serra da Capivara National Park, Piaui, Brazil, demonstrate the oldest dating to the presence of hookworm infections in pre-Columbian populations. The oldest is the site Boqueirão da Pedra Furada, dated 7,230 \pm 80 years, where were found eggs of Trichuris trichiura [34], followed by the Sítio do Meio, with datings between 7,000 and 9,000 years [35]. 
Hookworms and T. trichiura eggs were also found in human coprolites originating from the archaeological site Boqueirão Soberbo, dated $4,905 \pm 85$ to $1,325 \pm 60$ B.P. Acantochephala eggs were found in samples originating from the same archaeological site and with the same dating [36]. In 1980 and 1983, have been published the findings of Ferreira et al. [36,37] with diagnosis of the presence of hookworm eggs and T. trichiura in coprolites dated to $3,490 \pm 120-430 \pm 70$ B.P. found at the archaeological site Gruta do Gentio II, Unaí, Minas Gerais. In samples of the same dating site 3,490 $\pm 120-430 \pm 70$ B.P., Ascaris lumbricoides and acanthocephala were found, and samples dated up to 3,500 years have revealed the presence of the larvae of 3 developmental stages of the intestinal worm, Strongyloides stercoralis, thus explaining that the climatic conditions to which specimens are subjected can facilitate hatching of the eggs and larval development [38].

Eggs of T. trichiura and A. lumbricoides were found in coprolites from the archaeological site Lapa Pequena, Minas Gerais (8,000-7,000 BP) [35]. From the Municipality of Itacambira, north of Minas Gerais state, were found eggs of Trichostrongylidae and T. trichiura in a mummified body of the Brazilian colonial period $[39,40]$. Years later, with the application of molecular biology techniques in soft and bone tissues from the same mummy, it was possible to diagnose DNA fragments of Leishmania tarentolae [16].

Ferreira et al. [41] in 1989 analyzed samples (2,000 B.P.) from the archaeological site of Furna do Estrago, in Pernambuco. They found T. trichiura eggs. Eggs of the same parasites, of A. lumbricoides and Hymenolepis nana, were found in samples dating from 4,000-2,000 B.P. originating from Santa Elina, Mato Grosso [35]. Coprolite samples belonging to a mummy found in the archaeological site Lapa do Boquete, Minas Gerais, dated 600-1,200 B.P. revealed the presence of Echinostoma spp. eggs [42].

Some samples of coprolites previously analyzed by optical microscopy and presenting a negative result for the presence of A. lumbricoides, were submitted to molecular biology technique. It was possible to give the diagnosis of DNA fragments of this helminth in samples of human coprolites originating from archaeological sites Toca do Meio, Serra da Capivara National Park, Piaui (8,800 \pm 60 B.P.) and Lapa Pequena, Minas Gerais (8,000-7,000 B.P.) [38]. The molecular technique of PCR was used by Fernandes et al. [13] in 2008 for diagnosing DNA fragments of T. cruzi I in soft and bone tissues, as well as fecal mass collected from a mummy found on the site Vale do
Peruaçu, Minas Gerais, dated $560 \pm 40$ years ago. In the same year, Lima et al. [43] found DNA fragments of T. cruzi in bone tissue of a mummy 7,000-4,500 B.P. from the same locality.

As mentioned before, more recent studies with the application of PCR technique was performed in soft tissue samples and collected bone in a mummy (colonial period) adult male, found in the basement of the Church of Santo Antonio Aparecido, in the Minas Gerais state. Viscera and bone tissues, including bone marrow samples, revealed the presence of DNA fragments of L. tarentolae [16]. A species of Leishmania not pathogenic to humans, belonging to the Old World and which has lizard reptiles as the hosts, was found [44-50]. All findings are listed in Table 1.

\section{PALEOPARASITOLOGICAL FINDINGS IN SAMPLES FROM ARGENTINA}

Human coprolites (1,000-500 B.P.) found in the archaeological site Valle Encantado, Neuquén, Argentina were analyzed with encountering of eggs of hookworms and Trichostrongylus spp. [33]. While, E. vermicularis eggs were found in coprolites from the pre-Columbian period in the site Pie de Palo [51].

In 2006, Fugassa et al. [52] reported the presence of T. trichiura eggs in coprolites found in the archaeological site Nombre de Jesús, in Cabo Virgenes, a Spanish settlement in Patagonia. Samples of the same archaeological site presented eggs of A. lumbricoides [52]. Eggs of Ascaris sp. were found in samples from the site Orejas de Burro, Santa Cruz, dated 3,720-3,978 B.P. and T. trichiura eggs in samples of the site Parador Nativo, dated 1,513 \pm 48 B.P. and Centro Minero, dated $689 \pm 44$ B.P. Both sites are located in the Rio Negro region [52].

Fugassa [53] in 2006 recorded a larva and hookworm eggs in the Patagonia samples dating from $8,920 \pm 200$ years B.P. In 2008, Fugassa et al. [54] analyzed samples from the site Perito Moreno, Santa Cruz, dated 6,540 \pm 110 B.P., finding eggs of $E$. vermicularis and Trichuris sp. and a rhabditoid larva. In samples of sites Las Mandibulas (6,540 \pm 110 B.P.) and Caleta Falsa, in Tierra del Fuego (850 B.P.), the samples presented eggs of Capillaria spp. [55].

Not only in human coprolites were recorded the presence of hookworms, as well as in animals coprolites. In the same region of Argentina, Fugassa et al. [52] in 2006 also found eggs of Uncinaria genus in canid coprolites, dated to $6,540 \pm 110$ years. All findings are listed in Table 1. 
Table 1. Paleoparasitological findings from South America

\begin{tabular}{|c|c|c|c|}
\hline Country & Locality & Archaeological site & Parasites found \\
\hline \multirow[t]{4}{*}{ Brazil } & $\begin{array}{l}\text { Piauí (National Park } \\
\text { Serra da Capivara) }\end{array}$ & $\begin{array}{l}\text { Boqueirão da Pedra Furada } \\
\text { Sítio do Meio } \\
\text { Boqueirão Soberbo }\end{array}$ & $\begin{array}{l}\text { ancylostomids, Trichuris trichiura } \\
\text { ancylostomids, Ascaris lumbricoides } \\
\text { ancylostomids, T. trichiura, acantocephala }\end{array}$ \\
\hline & Minas Gerais & $\begin{array}{l}\text { Gruta do Gentio II, Unaí } \\
\text { Lapa Pequena } \\
\text { Vale do Peruaçu } \\
\text { Itacambira } \\
\text { Lapa do Boquete }\end{array}$ & $\begin{array}{l}\text { T. trichiura, A. lumbricoides, acanthocephala, Strongyloides stercoralis } \\
\text { (larvae) } \\
\text { T. trichiura, A. lumbricoides }{ }^{\text {a }} \\
\text { Trypanosoma cruzi (DNA analysis) } \\
\text { Trichostrongylidae, T. trichiura, Leishmania tarentolae (DNA analysis) } \\
\text { Echinostoma spp. }\end{array}$ \\
\hline & Pernambuco & Furna do Estrago & T. trichiura \\
\hline & Mato Grosso & Santa Elina & T. trichiura, A. lumbricoides, Hymenolepis nana \\
\hline \multirow[t]{6}{*}{ Argentina } & Neuquén & $\begin{array}{l}\text { Valle Encantado } \\
\text { Pie de Palo }\end{array}$ & $\begin{array}{l}\text { ancylostomids, Trichostrongylus spp. } \\
\text { Enterobius vermicularis }\end{array}$ \\
\hline & Cabo Virgenes & Nombre de Jesús & T. trichiura, A. lumbricoides \\
\hline & Santa Cruz & $\begin{array}{l}\text { Orejas de Burro } \\
\text { Perito Moreno }\end{array}$ & $\begin{array}{l}\text { Ascaris sp. } \\
\text { E. vermicularis, Trichuris sp., rabditoid larva }\end{array}$ \\
\hline & Rio Negro & $\begin{array}{l}\text { Parador Nativo } \\
\text { Centro Minero }\end{array}$ & $\begin{array}{l}\text { T. trichiura } \\
\text { T. trichiura }\end{array}$ \\
\hline & Patagonia & - & ancylostomids (larvae and eggs) \\
\hline & Tierra del Fuego & $\begin{array}{l}\text { Las Mandibulas } \\
\text { Caleta Falsa }\end{array}$ & $\begin{array}{l}\text { Capillaria spp. } \\
\text { Capillaria spp. }\end{array}$ \\
\hline \multirow[t]{7}{*}{ Chile } & $\begin{array}{l}\text { Santiago }- \\
- \\
-\end{array}$ & $\begin{array}{l}\text { Cerro El Plomo } \\
\text { Atacama } \\
\text { Cabuza } \\
\text { Tihuanaco }\end{array}$ & $\begin{array}{l}\text { T. trichiura, Entamoeba spp. } \\
\text { Entamoeba sp. }\end{array}$ \\
\hline & Atacama Desert & $\begin{array}{l}\text { Northern Chile } \\
\text { Skulls found in the Atacama Desert. } \\
\text { Chinchorros mummies (Found in Illo, } \\
\text { A region of Peru to Antofagasta) }\end{array}$ & $\begin{array}{l}\text { Paragonimus sp. } \\
\text { T. cruzi (DNA analsysis) } \\
\text { Leishmania spp. (DNA analysis) } \\
\text { T. cruzi (DNA analysis) }\end{array}$ \\
\hline & lquique & Tiliviche & Diphyllobothrium spp., ancylostomids, E. vermicularis \\
\hline & San Pedro de Atacama & $\begin{array}{l}\text { Toconao Oriente } \\
\text { Tulan } \\
\text { Catarpe } 2 \\
\text { Bodies stored in the Archaeological } \\
\text { Museum of San Pedro de Acatacama }\end{array}$ & $\begin{array}{l}\text { ancylostomids } \\
\text { E. vermicularis, T. trichiura, Trichostrongylus spp. } \\
\text { T. trichiura, Trichostrongylus spp. } \\
\text { T. cruzi (DNA analysis) }\end{array}$ \\
\hline & Tarapaca Calley & Caserones & E. vermicularis \\
\hline & North Chile & - & Diphyllobothrium pacificum \\
\hline & Arica & $\begin{array}{l}\text { San Miguel de Azapa } \\
\text { Lluta Valley } \\
\text { Alto Ramirez }\end{array}$ & $\begin{array}{l}\text { Diphyllobothrium sp. } \\
\text { T. trichiura, H. nana } \\
\text { Entamoeba sp. }\end{array}$ \\
\hline \multirow[t]{7}{*}{ Peru } & Chicama Valley & Huaca Prieta & Diphyllobothrium spp. \\
\hline & Huarmey Valley & $\begin{array}{l}\text { Los Gavilanes } \\
\text { A mummy of the Murga culture } \\
\text { - }\end{array}$ & $\begin{array}{l}\text { D. pacificum } \\
\text { T. trichiura } \\
\text { A. lumbricoides } \\
\text { E. vermicularis }\end{array}$ \\
\hline & Coast of Peru & - & D. pacificum \\
\hline & Osmore & - & D. pacificum \\
\hline & Coastal Southern Peru & $\begin{array}{l}\text { A mummy Tihuanaco (Found in a } \\
\text { gallery burial) } \\
\text { Huari }\end{array}$ & $\begin{array}{l}\text { ancylostomids } \\
\text { Entamoeba spp. }\end{array}$ \\
\hline & Cuzco Valley & $\begin{array}{l}\text { Mummy of the Inca Civilization } \\
\text { (Part of the collection of National } \\
\text { Museum of Anthropology and } \\
\text { Ethnology, Florence). }\end{array}$ & T. cruzi (histological analysis) \\
\hline & - & A child peruvian mummy & Leishmania spp. (immunohistochemical technique) \\
\hline
\end{tabular}

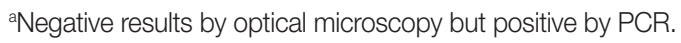




\section{PALEOPARASITOLOGICAL FINDINGS IN SAMPLES FROM CHILE}

One of the first paleoparasitological studies in samples from archaeological sites in Chile was done by Pizzi and Schenone [32] in 1954, and they diagnosed T. trichiura and Entamoeba spp. in coprolites found on the site Cerro El Plomo in Santiago, dating from the pre-Columbian period. Records of Entamoeba sp. were made years later in coprolites from the preColumbian period originating from the archaeological sites Alto Ramirez, Atacama, Cabuza and Tihuanaco [56]. In 1976, in coprolites of an archaeological site located in the Atacama Desert, Hall [57] found eggs of Paragonimus sp.

Samples dating from 4,110-1,950 B.C. (before Christ) found in the archaeological site Tiliviche in Iquique, Chile showed the presence of Diphyllobothrium spp. eggs, suggesting a specific type of food for individuals of that population [58]. More recent studies on samples from the same location and the same period showed the presence of hookworm eggs and E. vermicularis [35]. Hookworm eggs were also found in coprolites originating from the archaeological site Toconao Oriente, located in San Pedro de Atacama, dating of 2,500-2,100 B.P. [35]. Reinhard and Aufderheide [59] in 1990 diagnosed samples dated 4,000 B.P., found in archaeological site in northern Chile, the presence of Diphyllobothrium pacificum eggs, and in 2003, studies were published by Reinhard and Urban [60] who diagnosed Diphyllobothrium sp. eggs in samples of the archaeological site of San Miguel de Azapa, dated 4,000-5,000 A.P. (after present) [60].

Analyses performed in coprolites found at the site Tulan also located in San Pedro de Atacama, dated 4,100 B.C.-800 A.D. (Anno Domini), and at the site Caserones, Tarapaca Valley, diagnosed the presence of $E$. vermicularis eggs [61,62]. In other samples originating from Tulan site, San Pedro de Atacama, dating from 1,000 B.C. were found T. trichiura eggs [63] and in those dated 1,080-950 B.C., were found T. trichiura and Trichostrongylus spp. eggs [35]. The latter was also found in samples of archaeological site Catarpe 2, San Pedro de Atacama, dating from 1,450-1,525 A.D. In samples from the site Lluta Valley, in Arica belonging to the Inca period, dated 1,200-1,500 A.D., were found eggs of T. trichiura and H. nana [64].

In 1985, Rothhammer et al. [65] described in mummies found in the Atacama Desert (470 B.C. and 600 A.D.) cardiac lesions consistent with chronic Chagas' disease. Suspicions for the presence of T. cruzi infection in mummy 4,000 B.P. from the Atacama Desert, northern Chile, have led to the analysis by PCR technique, confirming the presence of DNA fragments of the parasite in the heart, esophagus, and colon tissues $[66,67]$. Mummified tissues were collected from bodies stored in the Archaeological Museum of San Pedro de Atacama, northern Chile, dated to 2,000 B.P.-1,400 A.D. In 4 of 6 samples analyzed, it was possible to recover T. cruzi DNA through the PCR technique [9]. Madden et al. [68] in 2001 and Aufderheide et al. [69] in 2004 diagnosed DNA fragments of T. cruzi in mummies $(9,000$ B.P.) belonging to the Chinchorros culture.

Samples originating from Chilean mummies were also analyzed in search for the presence of Leishmania parasites. Costa et al. [70] in 2009 identified disfiguring bone lesions, mucosal leishmaniasis characteristics in the skulls of 4 women found in the Atacama Desert. The application of molecular PCR technique diagnosed the presence of Leishmania DNA fragments in 3 analyzed individuals. All findings are listed in Table 1.

\section{PALEOPARASITOLOGICAL FINDINGS IN SAMPLES FROM PERU}

Analyses conducted in human coprolites of the site Huaca Prieta, Peru, from 3,000 B.C. showed the presence of Diphyllobothrium spp. eggs [71]. In 1983, Patrucco et al. [72] found eggs of $D$. pacificum in samples of the site Huamey Valley, dated 2,700-2,850 B.C. In archaeological site located in the region of the coast of Peru, Patrucco et al. [72] in 1983 found eggs of the same parasite dating 10,000-4,000 B.P. In Osmore, Peru, the same authors found eggs of $D$. pacificum in samples dating in 1,020-1,476 B.P. [72].

Coprolite samples (890-950 A.D.) collected from cavity of a mummy Tihuanaco revealed the presence of hookworm eggs [73]. Samples of the site Huamey Valley, 1,000 A.D. [72] and a mummy belonging to Murga culture, Colonial period [56], presented T. trichiura eggs. While the analysis of another sample of the site huarmey Valley, dated 2,277 \pm 181 B.C. revealed eggs of A. lumbricoides and E. vermicularis [72]. From the archaeological site Huari, a sample of pre-Columbian period was diagnosed with the presence of Entamoeba spp. [56].

Fornaciari et al. [74] in 1992, analyzing a Peruvian mummy belonging to the Inca civilization, noted lesions with evidence of Chagas disease. The histological analysis showed the presence of amastigote nests in the heart of this mummy muscle tissue. Studies in a Peruvian mummy of 6 years old, dated 800 B.C. revealed the presence of macrophages with Leishmania by 
immunohistochemical technique [75]. All findings are listed in Table 1.

\section{INTERACTION BETWEEN SOME PARASITES, HUMANS, AND ENVIRONMENT}

Many of the parasites found in archaeological material and mentioned in this review originated in human populations of the Old World [76]. They went out of Africa with the peopling of Europe and from there they dispersed around the world where climatic conditions allow the transmission [77]. However, humans have acquired other parasites of animals, since humans invaded new habitats or creating new habits adopting new technologies, thus expanding its range of influence on the environment. Cockburn [78] in 1980 discussed on the association of humans with their parasites since its formation as a species, considering data from the paleoparasitology and their cultural behavior to explain the acquisition of parasites via phylogenetic and ecological [78].

Humans have adopted alimentary habits according to occupied areas. This is evidenced by paleoparasitological analysis in coprolites with findings of $D$. pacificum eggs. Intestinal infection by this parasite was common in the past as it is today in the Pacific coast region. The consumption of raw fish is a common habit in many countries and cultures around the world. Baer et al. [79] in 1967 reported the presence of D. pacificum in modern population of the Peruvian coast, afterward the infection by this parasite was confirmed in Peru and Chile through paleoparasitological analysis in coprolites of pre-Columbian origin $[60,63,72,80]$. Human transmission of $D$. pacificum occurs through raw fish consumption containing this parasite.

Regarding eggs Echinostoma sp. found in a Brazilian mummy [42] and the fact that this parasite has not been recorded in modern population of South America, the discovery was carefully researched before publication. It is interesting that in an article published by Fernandes et al. [13] in 2008, cases of human Echinostoma sp. infection in prehistoric population of South America was associated with a case of Chagas disease with intestinal lesions characterized by megacolon. In this case, 2 important points should be emphasized. First, the description of injuries caused by Chagas disease in a mummy out of the Andean region was confirmed by studies of molecular paleoparasitology [13]. Second, infection by Echinostoma spp. in the South American human population has not yet been described [42]. These findings pointed toward the need for more detailed studies on the archaeological sites where the samples were analyzed [81].

As mentioned earlier in this paper, hookworm findings revealed a possible entry of this parasite and human by a transpacific route. For being a geohelminth, this parasite needs the soil for their maturity, and cold temperatures have destroyed their eggs [82]. The idea defended by Araújo and Ferreira [82] in 1996 is also valid for the introduction of T. trichiura and $S$. stercoralis infections [83]. Even though considering the durability of whipworm eggs, cold Arctic conditions would not have allowed their survival and development on the soil. The possibility of autoinfection in S. stercoralis contributes to the permanence of this disease for a few years in the human host after the initial infection, but it mostly occurs in severe forms and immunodeficient host. Thus, the natural cycle of the parasite would not explain its persistence during the migration process of peopling of the Americas [84]. The same idea of a transpacific route of infection by A. lumbricoides would be compatible.

In contrast to the hookworm, the pinworm infection caused by E. vermicularis does not need to pass through the soil to transmit from one host to another, so their persistence in a given human population depend on climatic conditions. It could therefore have been brought from the old to the new continent, including by human migrations across the Bering Strait. This may explain the greater geographic dispersion of the findings and its spread in North America, from 10,000 years to the present time [82].

The origin and spread of human infections with T. cruzi is discussed in many works, as well as the approach of molecular paleoparasitology, and which may represent in an evolutionary perspective [9]. Findings of genetic material from T. cruzi in mummies of the Chinchorro culture presented a static epidemiological pattern of the disease with a prevalence rate $(40.6 \%)$ approximately constant throughout this period of time. These observations suggest a sylvatic cycle of Chagas disease. It was probably well established at the time with the first humans (members of the Chinchorro culture) when they established the first settlement in the Andean coast for nearly 9,000 years. Thus, they began to participate in this sylvatic cycle, probably aggravated by the various forms of ingestion of the trypanosomatid, including the ingestion of contaminated food. Gradually the domestic cycle began to evolve, leading to its current status [69].

The description of typical lesions of Chagas disease and a 
positive PCR for T. cruzi in mummies from pre-Columbian countries, dating 9,000 years ago, showed the antiquity of the infection and disease in humans $[9,65-67,69,74]$. Moreover, the observations made by Dr. Adauto Araújo about the entrance of T. cruzi in America, specifically in Southeast region of Piaui, Brazil, showed a scenario that supports the hypothesis that Chagas disease is as old as the presence of humans in the Americas. In 1984, during the excavations of the archaeological site Boqueirão da Pedra Furada, Serra da Capivara National Park, Piauí, Northeastern Brazil, coordinated by Dr. Niéde Guidon [85,86], Dr. Adauto Araújo and other researchers saw that archaeologists were attacked by triatomine while they were studying the cave paintings of sandstone walls that make up the rock shelter under the old prehistoric camp.

The paintings are all over the wall and, at the period, it was necessary to copy them covered with a transparent plastic. Early in the morning as in the hottest hours of the day, and at night when the temperature drops, emerged nymphs and adults of Triatoma brasiliensis trying to feed on the blood of archaeologists, students, and workers of the excavations. Some specimens were infected with T. cruzi. Thus, it was postulated that the ancient artists, as well as inhabitants of the rock shelters, have also been attacked and infected by the parasite [9]. According to the findings in the Brazilian Northeast, the first prehistoric occupations in the region of Serra da Capivara National Park occurred thousands of years before 15,000-12,000 years accepted for the peopling of South America $[87,88]$. Although the dates still raise controversy [89], caves and rock shelters containing numerous cave paintings, some dating back 26,000 years attest to the antiquity of this occupation.

The finding of macrophages with Leishmania in Peruvian mummy of a girl of 6 years old, dating from 800 B.C. was of great importance because it shows that one of the forms of leishmaniasis (cutaneous leishmaniasis) existed in the Americas long before the coming of the European colonizers [75]. The first evidence of the encounter of $L$. tarentolae DNA fragments of the mummy from the colonial period found in the Minas Gerais state, Brazil induces numerous questions. Despite current knowledge of this Leishmania species, as being non-pathogenic to humans, here the authors extend backwards to the Brazilian Colonial Period (end of 18th century/beginning of the 19th century) new evidence for $L$. tarentolae molecular signatures in soft and hard tissue biopsies, bone marrow included, from this mummy. The finding implies that a systemic spread of the parasite occurred and led us to speculate that a $L$. tarentolae strain, possibly now extinct, had visceralization ability. The findings re-opened the discussion concerning the potential survival of an ancient $L$. tarentolae strain within human macrophages and its ability to spread systemically [16].

Many studies still need to be made in the field of paleoparasitology to uncover the issues of parasite-host-environment relationships. The techniques used for the diagnosis of parasites in archaeological origin materials constantly improve aiming to be more accessible the parasitological diagnosis and explanations about the peopling of the Americas and the entry of the parasites in our continent.

The data acquired by paleoparasitological studies is extremely important for experts and interested in the peopling of the Americas [90], since the parasites found in archaeological material are excellent markers to trace human migrations in the past [33].

\section{CONFLICT OF INTEREST}

We have no conflict of interest related to this study.

\section{REFERENCES}

1. Ruffer MA. Note on the presence of Bilharzia haematobia in Egyptian mummies of the twentieth dynasty. Br Med J 1910; 1: 16.

2. Szidat L. Über die Erhaltungsfähigkeit von Helmintheneiern in Vor- und Frühgeschichtlichen Moorleichen. Z Parasitenkd 1944; 13: 265-274.

3. Cockburn TA. The evolution and eradication of infectious diseases. Perspect Biol Med 1964; 7: 498-499.

4. Fonseca O. Parasitismo e migrações humanas pré-históricas. Rio de Janeiro, Brazil. Mauro Familiar. 1972, p 446.

5. Ferreira LF, Araújo A. On hookworm in the Americas and transpacific contact. Parasitol Today 1996; 12: 454.

6. Gonçalves ML, Araújo A, Ferreira LF. Paleoparasitologia no Brasil. Cien Saude Colet 2002; 7: 191-196.

7. Ferreira LF, Araújo A, Confalonieri U. Paleoparasitologia no Brasil. Rio de Janeiro, Brazil. PEC/ENSP-FIOCRUZ. 1988.

8. Araújo A, Ferreira LF, Confalonieri U. A contribution to the study of helminth findings in archaeological material in Brazil. Rev Bras Biol 1981; 41: 873-881.

9. Ferreira LF, Britto C, Cardoso MA, Fernandes O, Reinhard K, Araújo A. Paleoparasitology of Chagas disease revealed by infected tissues from Chilean mummies. Acta Trop 2000; 75: 7984.

10. Lutz A. Schistosomum mansoni ea Schistosomatose Scgundo obscrvações feitas no Brazil. Mem Inst Oswaldo Cruz 1919; 11: 121-150.

11. Araújo A, Reinhard K, Bastos OM, Costa LC, Pirmez C, Iñiguez A, 
Vicente AC, Morel CM, Ferreira LF. Paleoparasitology: perspectives with new techniques. Rev Inst Med Trop Sao Paulo 1998; 40: 371-376.

12. Zink AR, Spigelman M, Schraut B, Greenblatt CL, Nerlich AG, Donoghue HD. Leishmaniasis in ancient Egypt and Upper Nubia. Emerg Infect Dis 2006; 12: 1616-1617

13. Fernandes A, Iñiguez AM, Lima VC, Souza SM, Ferreira LF, Vicente AC, Jansen AM. Pre-Columbian Chagas disease in Brazil: Trypanosoma cruzi I in the archaeological remains of a human in Peruaçu Valley, Minas Gerais, Brazil. Mem Inst Oswaldo Cruz 2008; 103: 514-516.

14. Nerlich AG, Bianucci R, Trisciuoglio A, Schönian G, Ball M, Giuffra V, Bachmeier B, Pusch CM, Ferroglio E, Fornaciari G. Visceral leishmaniasis during Italian Renaissance, 1522-1562. Emerg Infect Dis 2012; 18: 184-186.

15. Bianucci R, Giuffra V, Bachmeier BE, Ball M, Pusch CM, Fornaciari G, Nerlich AG. Eleonora of Toledo (1522-1562): evidence for tuberculosis and leishmaniasis co-infection in Renaissance Italy. Int J Paleopathol 2012; 2: 231-235.

16. Novo SP, Leles D, Bianucci R, Araújo A. Leishmania tarentolae molecular signatures in a 300-hundred-years-old human Brazilian mummy. Parasit Vectors 2015; 8: 72.

17. Bastos OM, Araújo A, Ferreira LF, Santoro A, Wincker P, Morel CM. Experimental paleoparasitology: identification of Trypanosoma cruzi DNA in desiccated mouse tissues. Paleopathol Newsl 1996; 94: 5-8.

18. Guhl F, Jaramillo C, Vallejo GA, Cárdenas A-Arroyo F, Aufderheide A. Chagas disease and human migration. Mem Inst Oswaldo Cruz 2000; 95: 553-555.

19. Dittmar K. Old parasites for a new world: the future of paleoparasitological research. J Parasitol 2009; 95: 365-371.

20. Raoult D, Drancourt M. Paleomicrobiology: Past Human Infections. Berlin-Heidelberg, Germany. Springer-Verlag. 2008.

21. Gonçalves ML, Araújo A, Duarte R, da Silva JP, Reinhard K, Bouchet F, Ferreira LF. Detection of Giardia duodenalis antigen in coprolites using a commercially available enzyme-linked immunosorbent assay. Trans R Soc Trop Med Hyg 2002; 96: 640-643.

22. Gonçalves ML, da Silva VL, de Andrade CM, Reinhard K, da Rocha GC, Le Bailly M, Boucher F, Ferreira LF, Araújo A. Amoebiasis distribution in the past: first steps using an immunoassay technique. Trans R Soc Trop Med Hyg 2004; 98: 88-91.

23. Le Bailly M, Gonçalves ML, Harter-Lailheugue S, Prodéo F, Araújo A, Bouchet F. New finding of Giardia intestinalis (Eukaryote, Metamonad) in Old World archaeological site using immunofluorescence and enzyme-linked immunosorbent assays. Mem Inst Oswaldo Cruz 2008; 103: 298-300.

24. Wilke PJ, Hall HJ. Analysis of ancient feces: a discussion and annotated bibliography. Archaeological Research Facility, Department of Anthropology, Berkeley, University of California. 1975.

25. Araújo A, Jansen AM, Bouchet F, Reinhard K, Ferreira LF. Parasitism, the diversity of life, and paleoparasitology. Mem Inst Oswaldo Cruz 2003; 98 (suppl 1): 5-11.

26. Ortega YR, Bonavia D. Cryptosporidium, Giardia, and Cyclospora in ancient Peruvians. J Parasitol 2003; 89: 635-636.

27. Arriaza BT, Schwartz JH. Beyond death: the Chinchorro mummies of ancient Chile. Washington DC, USA. Smithsonian Institution Press. 1995.

28. Fugassa M, Guichón R. Análisis paleoparasitológico de coprolitos hallados en sítios arqueológicos de Patagonia austral: definiciones y perspectivas. Magallania 2005; 33: 13-19.

29. Ferreira LF, Reinhard K, Araújo A. Fundamentos da Paleoparasitologia. Rio de Janeiro, Brazil. Editora Fiocruz. 2011, p 484.

30. Freitas O. Doenças Africanas no Brasil. São Paulo, Brazil. Editora Nacional, Coleção Brasiliana. 1935, p 51.

31. Carvalho DM. Doenças dos escravizados; doenças africanas?. In Encontro Regional de História - Usos do Passado, XII, Niterói. Rio de Janeiro, Brazil. Associação Nacional de História (Anpuh)/ 2006.

32. Pizzi T, Schenone H. Hallazgo de huevos de Trichuris trichiura en contenido intestinal de un cuerpo arqueológico incaico. Bol Chil Parasitol 1954; 9: 54-59.

33. Araújo A, Reinhard K, Ferreira LF, Gardner SL. Parasites as probes for prehistoric human migrations? Trends Parasitol 2008; 24: 112-115.

34. Ferreira LF, Araújo A, Confalonieri U, Chame M, Ribeiro BM. Encontro de ovos de ancilostomídeos em coprólitos humanos datados de 7230 \pm 80 anos, Piauí, Brasil. An Acad Bras Cienc 1987; 59: 280-281.

35. Gonçalves ML, Araújo A, Ferreira LF. Human intestinal parasites in the past: new findings and a review. Mem Inst Oswaldo Cruz 2003; 98 (suppl 1): 103-118.

36. Ferreira LF, de Araújo AJ, Confalonieri UE. The finding of helminth eggs in a Brazilian mummy. Trans R Soc Trop Med Hyg 1983; 77: 65-67.

37. Ferreira LF, Araújo A, Confalonieri UEC. Finding of helminth eggs in human coprolites from Unaí, MG. Trans R Soc Trop Med Hyg 1980; 74: 798-800.

38. Leles D, Araújo A, Ferreira LF, Vicente AC, Iñiguez AM. Molecular paleoparasitological diagnosis of Ascaris sp. from coprolites: new scenery of ascariasis in pré-Colombian South America times. Mem Inst Oswaldo Cruz 2008; 103: 106-108.

39. Confalonieri UE, de Araújo AJ, Ferreira LF. Trichuris trichiura infection in Colonial Brazil. Paleopathol Newsl 1981; 35: 13-14.

40. Araújo A, Confalonieri U, Ferreira LF. Encontro de ovos de Trichostrongylidae e Trichuris trichiura em corpo mumificado do período colonial brasileiro. Rev Centr Cienc Biol Saúde 1984; 1: 11-16.

41. Ferreira LF, Araújo A, Confalonieri U, de Lima JM. Trichuris trichiura eggs in human coprolites from the archaeological site of Furna do Estrago, Brejo da Madre de Deus, Pernambuco, Brazil. Mem Inst Oswaldo Cruz 1989; 84: 581.

42. Sianto L, Reinhard KJ, Chame M, Chaves S, Mendonça S, Gonçalves ML, Fernandes A, Ferreira LF, Araújo A. The finding of Echinostoma (Trematoda: Digenea) and hookworm eggs in coprolites collected from a Brazilian mummified body dated 6001,200 years before present. J Parasitol 2005; 91: 972-975. 
43. Lima VS, Iñiguez AM, Otsuki K, Ferreira LF, Araújo A, Vicente $\mathrm{AC}$, Jansen AM. Chagas disease in ancient hunter-gatherer population, Brazil. Emerg Infect Dis 2008; 14: 1001-1002.

44. Chatton E, Blanc G. Existence de corps leishmaniformes dans les hématoblastes d'un gecko barbaresque Tarentolae mauritanica L Gunth. C R Soc Biol 1914; 77: 430-433.

45. Elwasila M. Leishmania tarentolae Wenyon, 1921 from the gecko Tarentola annularis in the Sudan. Parasitol Res 1988; 74: 591-592.

46. Laveran A, Franchini G. Des hematozoaires du gecko et specialement de Herpetomonas tarentolae, Procédé simple de culture des Herpetomonas. Bull Soc Pathol Exot 1921; 14: 323-326.

47. Adler S, Theodor O. Investigation of Mediterranean kala azar. X. A note on Trypanosoma platydactyli and Leishmania tarentolae. Proc R Soc Lond B Biol Sci 1931; 116: 543-544.

48. Parrot L, Foley H. Sur la frequence de la leishmaniose du gecko dans le Sud oranais. Arch Inst Pasteur Alger 1939; 17: 231-232.

49. Rioux JA, Knoepfler LP, Martini A. Presence en France de Leishmania tarentolae Wenyon, 1921 parasite du gecko Tarentola mauritanica. Ann Parasitol Hum Comp 1969; 44: 115-116.

50. Pozio E, Gramiccia M, Gradoni L, Maroli M. Hemoflagellates in Cyrtodactylus kotschyi (Steindachner, 1870) (Reptilia, Geckkonidae) in Italy. Acta Trop 1983; 40: 399-400.

51. Zimmerman MR, Morilla RE. Enterobiasis in pre-Columbian America. Paleopathol Newsl 1983; 42: 8.

52. Fugassa MH, Araújo A, Gichón RS. Quantitative paleoparasitology applied to archaeological sediments. Mem Inst Oswaldo Cruz 2006; 101 (suppl 2): 29-33.

53. Fugassa MH, Denegri GM, Sardella NH, Araújo A, Guichón RA, Martinez PA, Civalero MT, Aschero C. Paleoparasitological records in a canid coprolite from Patagonia, Argentina. J Parasitol 2006; 92: 1110-1113.

54. Fugassa MH, Sardella NH, Guichón RA, Denegri GM, Araújo A. Paleoparasitological analysis applied to museum-curated sacra from meridional Patagonian collections. J Archaeol Sci 2008; 35: 1408-1411.

55. Fugassa MH, Taglioretti V, Gonçalves ML, Araújo A, Sardella NH, Denegri GM. Capillaria spp. eggs in Patagonian archaeological sites: statistical analysis of morphometric data. Mem Inst Oswaldo Cruz 2008; 103: 104-105.

56. Fouant MM, Allison M, Gerszten E, Focacci G. Parasitos intestinais entre los indigenas precolombinos. Rev Chungara 1982; 9: 285-299.

57. Hall HJ. Untitled notes. Paleopathol Newsl 1976; 13: 9.

58. Ferreira LF, Araújo A, Confalonieri U, Chame M, Ribeiro Filho B. The finding of hookworm eggs in human coprolites from $7230 \pm 80$ years BP, from Piauí, Brazil. An Acad Bras Cienc 1987; 59: 280-281.

59. Reinhard KJ, Audderheide AC. Diphyllobothriasis in pre-Columbian Chile and Peru: adaptative radiations of a helminth species to native American populations. Papers on Paleopathology, 8th European Members Meeting, Cambridge, p 18.

60. Reinhard K, Urban O. Diagnosing ancient diphyllobothriasis from Chinchorro mummies. Mem Inst Oswaldo Cruz 2003; 98 (suppl 1): 191-193.

61. Ferreira LF, Araújo A, Confalonieri U, Nuñez L. Infecção por Enterobius vermicularis em populações agro-pastoris pré-colombianas de San Pedro de Atacama, Chile. Mem Inst Oswaldo Cruz 1989; 84 (suppl 4): 197-199.

62. de Araújo AJ, Ferreira LF, Confalonieri UE, Nuñez L, Ribeiro Filho BM. The finding of Enterobius vermicularis eggs in pre-Columbian human coprolites. Mem Inst Oswaldo Cruz 1985; 80: 141143.

63. Ferreira LF, de Araújo AJ, Confalonieri UE, Nuñez L. The finding of eggs of Diphyllobothrium in human coprolites $(4,100-1,950$ B.C.) from northern Chile. Mem Inst Oswaldo Cruz 1984; 79: 175-180.

64. Santoro C, Vinton SD, Reinhard KJ. Inca expansion and parasitism in the lluta valley: preliminary data. Mem Inst Oswaldo Cruz 2003; 98 (suppl1): 161-163.

65. Rothhammer F, Allison MJ, Nuñez L, Standen V, Arriaza B. Chagas' disease in pre-Columbian South America. Am J Phys Anthropol 1985; 68: 495-498.

66. Guhl F, Jaramillo C, Yockteng R, Vallejo GA, Cárdenas-Arroyo F. Trypanosoma cruzi DNA in human mummies. Lancet 1997; 349: 1370.

67. Guhl F, Jaramillo C, Vallejo GA, Yockteng R, Cárdenas-Arroyo F, Fornaciari G, Arriaza B, Aufderheide AC. Isolation of Trypanosoma cruzi DNA in 4000-year-old mummified human tissue from northern Chile. Am J Phys Anthropol 1999; 108: 401-407.

68. Madden M, Salo WL, Streitz J, Aufderheide AC, Fornaciari G, Jaramillo C, Vallejo GA, Yockteng R, Arriaza B, Cárdenas-Arroyo F, Guhl F. Hybridization screening of very short PCR products for paleoepidemiological studies of Chagas' disease. Biotechniques 2001; 30: 102-104, 106, 108-109.

69. Aufderheide AC, Salo W, Madden M, Streitz J, Buikstra J, Guhl F, Arriaza B, Renier C, Wittmers LE Jr, Fornaciari G, Allison M. A 9,000-year record of Chagas' disease. Proc Natl Acad Sci USA 2004; 101: 2034-2039.

70. Costa MA, Matheson C, Iachetta L, Llagostera A, Appenzeller O. Ancient leishmaniasis in a highland desert of northern Chile. PLoS One 2009; 4: e6983.

71. Callen EO, Camaron TWM. A prehistoric diet revealed in coprolites. New Sci 1960; 8: 35-40.

72. Patrucco R, Tello R, Bonavia D. Parasitological studies of coprolites of pre-hispanic Peruvian populations. Curr Anthropol 1983; 24: 393-394.

73. Allison MJ, Pezia A, Hasegawa I, Gerszten E. A case of hookworm infection in a pre-Columbian American. Am J Phys Anthropol 1974; 41: 103-106.

74. Fornaciari G, Castagna M, Viacava P, Tognetti A, Bevilacqua G, Segura EL. Chagas' disease in Peruvian Inca mummy. Lancet 1992; 339: 128-129.

75. Guillen S, Allison M. An early case of South American Leishmaniasis in Peru. 1st Paleopathology Association Meeting in South American; 2005. p. 61.

76. Araújo A, Ferreira LF. Oxiuríase e migrações pré-históricas. Hist 
Cienc Saude Manguinhos 1995; 2: 99-109.

77. Araújo A, Reinhard K, Ferreira LF. Parasite findings in archaeological remains: diagnosis and interpretation. Quat Int 2008; 180: $17-21$.

78. Cockburn TA. Palaeopathology and parasites. Microbiol Aust 1980; 1: 3-6.

79. Baer JG, Miranda H, Fernandez W, Medina J. Human diphyllobothriasis in Peru. Z Parasitenkd 1967; 28: 277-289.

80. Araújo A, Ferreira LF, Confalonieri UE, Nuñez L, Cruz FO. Eggs of Diphyllobothrium pacificum in precolumbian human coprolites. Paleopathol Newsl 1983; 41: 11-13.

81. Araújo A, Reinhard KJ, Leles D, Sianto L, Iñiguez A, Fugassa M, Arriaza B, Orellana N, Ferreira LF. Paleoepidemiology of intestinal parasites and lice in pre-Columbian South America. University of Nebraska 2015. digitalcommons.unl.edu.

82. Araújo A, Ferreira LF. Paleoparasitology and the peopling of the Americas. Fundhamentos 1996; 1: 106-114.

83. Reinhard K, Araújo A, Ferreira LF, Coimbra CE. American hookworm antiquity. Med Anthropol 2001; 20: 96-101.

84. Araújo A, Reinhard KJ, Gardner SL, Ferreira LF. Parasitos como marcadores de migrações pré-históricas. In: Ferreira LF, Reinhard K, Araújo A. Fundamentos da Paleoparasitologia. Rio de Janeiro: Editora Fiocruz; 2011.

85. Guidon N, Delibrias G. Carbon-14 dates point to man in the Americas 32,000 years ago. Nature 1986; 321: 769-771.

86. Guidon N. On stratigraphy and chronology of Pedra Furada. Curr Anthropol 1989; 30: 641-642.

87. Guidon N, Arnaud B. The chronology of New World: two faces of one reality. World Archaeol 1991; 23: 167-178.

88. Parenti F, Fontugne M, Guidon N, Guerin C, Faure M, Debard E. Chronostratigraphie des gisements archéologiques et paléontogiques de São Raimundo Nonata (Piauí, Brésil): contribution a la connaissance du peuplement pléistocène de l'Amérique. Mém Soc préhist fran 1999; 26: 327-332.

89. Meltzer DJ, Adovasio JM, Dillehay TD. On a Pleistocene human occupation at Pedra Furada, Brazil. Antiquity 1994; 68: 695-714.

90. Santos AKCR, Leite DS, Santos SEB. DNA mitochondrial em populações humanas pré-Colombianas da Amazônia e as interações do passado (paleogenética). In: Pereira E. Arqueologia da Amazônia. Belém: Museu Paraense Emílio Goeldi; 2010. 
